\title{
Global terrestrial isoprene emission models: sensitivity to variability in climate and vegetation
}

\author{
A. Arneth ${ }^{1,2}$, G. Schurgers ${ }^{1}$, J. Lathiere ${ }^{3}$, T. Duhl ${ }^{4}$, D. J. Beerling ${ }^{5}$, C. N. Hewitt ${ }^{6}$, M. Martin ${ }^{1}$, and A. Guenther ${ }^{4}$ \\ ${ }^{1}$ Physical Geography and Ecosystem Analysis, Lund University, Lund, Sweden \\ ${ }^{2}$ Karlsruhe Institute for Technology, Institute for Meteorology and Climate Research/Atmospheric Environmental Research \\ (IMK-IFU), Garmisch-Partenkirchen, Germany \\ ${ }^{3}$ Laboratoire des Sciences du Climat et de l'Environnement - LSCE-IPSL, CEA-CNRS-UVSQ, UMR8212, \\ Gif-sur-Yvette, France \\ ${ }^{4}$ NCAR, Boulder, Colorado, USA \\ ${ }^{5}$ Department of Animal and Plant Science, University of Sheffield, Sheffield S10 2TN, UK \\ ${ }^{6}$ Lancaster Environment Centre, Lancaster University, Lancaster LA1 4YQ, UK
}

Received: 13 March 2011 - Published in Atmos. Chem. Phys. Discuss.: 5 April 2011

Revised: 5 July 2011 - Accepted: 27 July 2011 - Published: 8 August 2011

\begin{abstract}
Due to its effects on the atmospheric lifetime of methane, the burdens of tropospheric ozone and growth of secondary organic aerosol, isoprene is central among the biogenic compounds that need to be taken into account for assessment of anthropogenic air pollution-climate change interactions. Lack of process-understanding regarding leaf isoprene production as well as of suitable observations to constrain and evaluate regional or global simulation results add large uncertainties to past, present and future emissions estimates. Focusing on contemporary climate conditions, we compare three global isoprene models that differ in their representation of vegetation and isoprene emission algorithm. We specifically aim to investigate the between- and within model variation that is introduced by varying some of the models' main features, and to determine which spatial and/or temporal features are robust between models and different experimental set-ups. In their individual standard configurations, the models broadly agree with respect to the chief isoprene sources and emission seasonality, with maximum monthly emission rates around $20-25 \mathrm{Tg}$ C, when averaged by 30 -degree latitudinal bands. They also indicate relatively small (approximately 5 to $10 \%$ around the mean) interannual variability of total global emissions. The models are sensitive to changes in one or more of their main model components and drivers (e.g., underlying vegetation fields, climate input) which can yield increases or decreases in total annual emis-
\end{abstract}

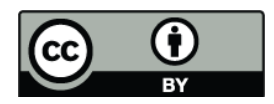

Correspondence to: A. Arneth (almut.arneth@nateko.lu.se) sions of cumulatively by more than $30 \%$. Varying drivers also strongly alters the seasonal emission pattern. The variable response needs to be interpreted in view of the vegetation emission capacities, as well as diverging absolute and regional distribution of light, radiation and temperature, but the direction of the simulated emission changes was not as uniform as anticipated. Our results highlight the need for modellers to evaluate their implementations of isoprene emission models carefully when performing simulations that use nonstandard emission model configurations.

\section{Introduction}

Isoprene emissions from terrestrial vegetation, mostly from forests and shrublands, dominate the global total emission source of biogenic volatile organic compounds (BVOCs). By mass, between 30 and $50 \%$ of the estimated total emission strength of BVOCs is in the form of isoprene (Guenther et al., 1995; Arneth et al., 2008a). Isoprene is a major precursor to the formation of tropospheric ozone in $\mathrm{NO}_{\mathrm{x}}$-polluted air (Atkinson, 2000), and it affects the levels of the troposphere's principal oxidant (the hydroxyl radical $\mathrm{OH}$; Poisson et al., 2000; Lelieveld et al., 2008) and hence the lifetime of methane. It also interacts with the growth of secondary organic aerosol (SOA) in a complex manner, being a precursor on the one hand (Claeys et al., 2004) while inhibiting SOA growth from monoterpene oxidation on the other (KiendlerScharr et al., 2009). Therefore, owing to its large source strength, and to its manifold reactions in the troposphere,

Published by Copernicus Publications on behalf of the European Geosciences Union. 
isoprene impacts on atmospheric burdens of substances that are relevant to both climate and health.

Isoprene production takes place in the chloroplast (Lichtenthaler, 1999), and emissions over the course of the day consequently vary strongly with temperature and light (Guenther et al., 1991). Models aiming to estimate global isoprene emissions typically combine algorithms in a multiplicative way to simulate this short-term variation as well as a more medium-term emission response to environmental changes (i.e., days to weeks; Guenther et al., 1995; Levis et al., 2003, Naik et al., 2004; Guenther et al., 2006; Lathière et al., 2006; Lathière et al., 2010). Some attempts have been made to link global estimates to the biochemical processes of chloroplastic isoprene production (Arneth et al., 2007a, b). In all cases, the starting point is a prescribed emission capacity or some analogue variable, $E$, that is defined for standard environmental conditions and vegetation functional units (e.g., plant functional types, PFTs), and that may be expressed on a leaf or canopy basis. The need to assign fixed values of emission capacities to PFTs remains of particular concern for the development of robust global models because of the known large species-to-species variation that exists within similar plant or vegetation functional groups. The determination of isoprene emission capacities for the larger vegetation groups via quantitative data assimilation techniques is further hampered by the limited amount of available leaf or canopy-level observations, and is confounded by the increasing number of observations that indicate that even the interpretation of individual emission capacity measurements in the field is non-trivial. A critical review of the concepts underlying isoprene modelling has recently been presented by Niinemets et al. (2010a, b).

Global-scale biogenic emissions cannot be constrained directly from observations, although recent efforts to infer emissions from satellite-based remote sensing represent a noteworthy top-down modelling approach. These use retrieved formaldehyde column data in combination with chemistry transport models for regional (Palmer et al., 2006; Barkley et al., 2008) and global (Shim et al., 2005; Stavrakou et al., 2009) estimates. Studies that seek to interpret the column formaldehyde information highlight the importance of not only the spatio-temporal patterns of emission but also of the type of atmospheric oxidation mechanism used together with the satellite-based or aircraft observations (Stavrakou et al., 2009, 2010; Barkley et al., 2011). Most bottom-up model simulations to date converge on a global isoprene emission strength of around $500 \pm 100 \mathrm{Tg} \mathrm{C} \mathrm{a}^{-1}$, despite not only large differences in the values of the assigned emission capacities and in the modelled processes, but also in how vegetation is represented and which climatology is used in the experiments (Arneth et al., 2008a; Ashworth et al., 2010). One recurring issue in the modelling of atmospheric burdens of $\mathrm{CO}$ or ozone in the troposphere has been that some chemistry transport models do not reproduce observationally-constrained values when using a biogenic source of isoprene on the or- der of $500 \mathrm{Tg} \mathrm{Ca}^{-1}$ (Prather et al., 2001). Whether or not this is related to emission estimates that are too high, to an incomplete understanding of isoprene oxidation pathways in the boundary layer and free troposphere, or to both is still not fully resolved. In today's atmospheric chemistry models, assumptions on the annual isoprene emission strength vary between around 200 and $600 \mathrm{Tg} C$ (Stevenson et al., 2006).

In the absence of global observational constraints on emissions, intercomparison of simulation outputs from different models can help to highlight critical patterns of emission estimates in which global models either converge or diverge. This can help to identify causes of large uncertainty and/or model sensitivity. Here we compare three global isoprene models that differ in their representation of vegetation and isoprene emission algorithm: MEGAN (Guenther et al., 2006), LPJ-GUESS (Arneth et al., 2007b), and BVOCEM (Lathière et al., 2010). These models have been evaluated individually against available observations at canopy scale, or satellite-sensing driven top-down modelling to ascertain their performance and sensitivity (Guenther et al., 2006; Arneth et al., 2007b; Lathière et al., 2010; Barkley et al., 2011). But to date no systematic analysis of between-model differences and the underlying contributing factors has been made. The chief objectives of this work are therefore to (i) highlight large sources of uncertainties in simulations of global isoprene emissions and to determine the degree of between- vs. within model variation that is introduced by varying some of the models' main features, and to (ii) determine which spatial and/or temporal features were robust between models and different experimental set-ups.

\section{Methods}

\subsection{Isoprene emission models}

LPJ-GUESS (Smith et al., 2001; Sitch et al., 2003) is a dynamic vegetation model that simulates global natural vegetation patterns and ecosystem carbon and water balance, as well as BVOC and fire emissions in response to variation in climate and atmospheric $\mathrm{CO}_{2}$ concentration. The model has been evaluated successfully against a number of benchmarks from the scale of the ecosystem to the globe (e.g., Smith et al., 2001; Lucht et al., 2002; Gerten et al., 2004; Sitch et al., 2003; Morales et al., 2005; Arneth et al., 2007b). In the work presented here, LPJ-GUESS is used with vegetation represented by 10 plant functional types and vegetation dynamics as in Sitch et al. (2003).

Isoprene production in LPJ is calculated by adopting the process-based isoprene emission algorithm of Niinemets et al. (1999) which infers the effects of temperature and light on emissions from the electron requirement for isoprene production. Here, we use a slightly updated version of the model presented by Arneth et al. (2007b), with an improved representation of the seasonality of emissions, as well as a simple 
energy balance to estimate canopy temperature from air temperature (Schurgers et al., 2011). The model can be applied for daily (Arneth et al., 2007b) to millennial (Schurgers et al., 2009) simulations, including a response to varying atmospheric $\mathrm{CO}_{2}$ levels that is linked to leaf internal $\mathrm{CO}_{2}$ concentration (Arneth et al., 2007b; Young et al., 2009), and a response to varying vegetation composition (Arneth et al., 2008b; Schurgers et al., 2009). In this study we assign static emission capacities to each of the model's globally applicable PFTs, an approach that is typical for all global BVOC models since no vegetation representation on species-level is available on that scale (likewise, we do not know emission capacities of most species in any case). For European forests, taking advantage of tree species-level simulations when the gap-model features of LPJ-GUESS are enabled (Smith et al., 2001), detailed simulations have demonstrated a more diverse spatial and temporal emission distribution compared to the use of global PFTs (Arneth et al., 2008b; Schurgers et al., 2009).

The starting point for calculating isoprene emissions with LPJ-GUESS is an analogue for a leaf-level emission capacity: the amount of electrons used for isoprene production (Niinemets et al., 1999; Arneth et al., 2007a) which has to be prescribed for each PFT and is specified for an air temperature of $30^{\circ} \mathrm{C}$ and light conditions equivalent to a photosynthetically-active radiation flux of $1000 \mu \mathrm{mol} \mathrm{m} \mathrm{m}^{-2} \mathrm{~s}^{-1}$. Input of spatially gridded, area-based emission capacities that take into account the vegetation mix at a given location (see MEGAN, BVOCEM, below) is therefore not necessary in this model. Being a dynamic global vegetation model (DGVM) that internally combines a canopy light-transfer model with the computation of a dynamicallychanging mix of vegetation, a canopy-based emission factor would be an output of the model, rather than an input. In fact, applying canopy-based emission factors that were calculated with a given canopy model using a prescribed vegetation product to models that use different canopy transfer and vegetation models would be, strictly speaking, incorrect, and introduces a large source of uncertainty. A similar argument applies when using leaf-level emission factors together with different leaf emission algorithms if the values of the emission factors are based on measurements that were performed under non-standard conditions (Niinemets et al., 2010b).

The Model of Emissions of Gases and Aerosols from Nature (MEGAN; Guenther et al., 2006) is a model framework that provides a variety of options including explicit or parameterized algorithms for representing isoprene response to environmental variables and landcover that can be based on remotely-sensed vegetation products, ground observations or output of dynamic vegetation models. MEGAN can be driven by gridded maps of emission capacities or by PFTbased emission capacities that are combined with mapped PFT distributions. For this comparison we have estimated hourly emission rates using the parameterized canopy model and isoprene response algorithms, the gridded isoprene emis- sion capacity maps, and remotely-sensed vegetation cover and leaf area indices derived from MODIS products (including crop fraction cover), based on Zhang et al. (2004) and Hansen et al. (2003), and as described by Guenther et al. (2006).

Isoprene emission calculations in MEGAN are based on the algorithms from Guenther et al. (1995). In the published version (Guenther et al., 2006) these are extended to account for effects of short- to medium term weather history, within-canopy variation in light and temperature, leaf age, soil moisture and $\mathrm{CO}_{2}$ concentration; soil moisture and direct $\mathrm{CO}_{2}$ effects are not included here. MEGAN uses empirical algorithms that simulate the processes controlling isoprene emissions, including a temperature response that simulates isoprene synthase activity; a light response that follows electron transport; $\mathrm{a} \mathrm{CO}_{2}$ response that reflects competition for PEP substrate; and a soil moisture response that shuts down isoprene emission when water availability is too low to support physiological activity. The implementation of the MEGAN $\mathrm{CO}_{2}$ response algorithm is described by Heald et al. (2009) and all other algorithms are described by Guenther et al. (2006). The gridded, canopy-based emission capacities used for these simulations are a model product that varies between grid cells based on the mix of vegetation in each location. That is, the emission capacities are not only calculated for standard light and temperature but also leaf area index (LAI), canopy age, sun angle, windspeed, humidity, soil moisture, $\mathrm{CO}_{2}$ concentration and weather history.

BVOCEM (Biogenic Volatile Organic Compound Emission Model; Lathière et al., 2010) is the third emission model used in this study, and is largely based on the parameterisations of Guenther et al. (2006). As with LPJ-GUESS and MEGAN, the model can in principle account for the effects of varying $\mathrm{CO}_{2}$ levels in the atmosphere on isoprene production (see Sect. 2.2), but applies the empirical function from Possell et al. (2005). Here, the vegetation distributions are calculated from the Sheffield Dynamic Vegetation Model (SDGVM; Woodward et al., 1995; Beerling and Woodward, 2001) but could also be provided by any model or satellitederived data and for any number of plant functional types; like for LPJ-GUESS, the calculated potential natural vegetation could be corrected for fractional crop cover (Lathière et al., 2010) but this feature was not applied in the present experiments. Lathiere et al. (2010) found a reduction of $12 \%$ of present-day isoprene emissions when taking anthropogenic land cover into consideration. The BVOCEM is driven with monthly inputs of air temperature, downward radiation flux, leaf area index and vegetation fraction for each PFT considered. For emission factors, expressed on a canopy area basis, BVOCEM adopts for each PFT the average value of the global gridded products supplied by MEGAN. The possibility to use the global maps from Guenther et al. (2006) is also available but was not used for the present study. 


\subsection{Experimental set-up}

A number of experiments were performed to examine the between-model spatial and temporal variability in global and regional emissions, focussing on the 1981-2002 period. For the dynamic vegetation models LPJ-GUESS and SDGVM/BVOCEM, runs were performed with the vegetation dynamic features enabled, following the standard procedure described in e.g., Sitch et al. (2003) and Woodward et al. (1995) while other experiments required that these models be run using prescribed vegetation (see below). The direct impacts of varying soil moisture, leaf age, or atmospheric $\mathrm{CO}_{2}$ concentrations on leaf isoprene emissions were not considered. The spatial resolution of each simulation experiment was $0.5^{\circ}$ by $0.5^{\circ}$.

Four simulation experiments are compared here based on the following set-up (for summary, see also Table 1):

1. A simulation using each model's standard published climatology, vegetation, and isoprene algorithm and emission factors

2. A simulation using different climate input compared to (1), but with each model's standard vegetation and emission factors. The DGVMs were run with either dynamic vegetation responding to the different climate (indicated by subscript "d"; LPJ-GUESS, SDGVM) or with vegetation fixed, with the fixed vegetation derived from the standard run (indicated by subscript "f”; LPJ-GUESS)

3. A simulation using different vegetation and emission factor input compared to (1), but each model's standard climate

4. A simulation using different vegetation, emission factor and climate input compared to (1).

\subsection{Climate}

Three different climate products are used by the three models for their standard simulations. These are from the Climatic Research Unit (CRU) of the University of East Anglia (Mitchell and Jones, 2005), which is the standard climate used for LPJ-GUESS; the National Center for Environmental Prediction (NCEP) reanalysis product (Kistler et al., 2001), used in the standard MEGAN simulation; and climate model output from the UK Met Office Unified Model (UM) (Stainforth et al., 2005), used for the standard BVOCEM simulation. BVOCEM has been globally applied and evaluated both with CRU and UM climate (Lathière et al., 2010).

Climate input data for the years 1981 to 2002 were used for the simulations, consisting of monthly radiation and temperature (both mean and diurnal amplitude). In the case of the BVOCEM standard simulations using UM climate, climate data was only available for one year (Lathière et al.,
2010). For LPJ-GUESS, the simulations of dynamic vegetation require monthly precipitation input since soil moisture patterns derived from the model's water balance calculations are necessary to drive photosynthesis. Simulations with fixed vegetation were based on prescribing soil moisture directly, the soil moisture patterns were taken from the dynamic simulations with CRU or NCEP as forcing. For the BVOCEM standard simulation, vegetation distribution and fraction were provided from SDGVM run with the UM monthly temperature, precipitation and relative humidity. In the following analysis, when comparing effects of changing climate on model output, we concentrate on CRU and NCEP products.

\subsection{Vegetation}

Following Sitch et al. (2003), LPJ-GUESS dynamically calculates potential natural vegetation as a mix of 10 plant functional types (PFTs). In brief, the PFT mix at a given location is the result of assigned PFT-specific bioclimatic limits, which constrain successful vegetation establishment and survival; the models' carbon and water balance calculations; and dynamical algorithms for carbon allocation, growth and mortality. The model thus calculates a seasonally- and interannually-varying leaf area index, and, in response to climate change, varying mixture of plant functional types. The Sheffield Dynamic Vegetation Model (Woodward et al., 1995), from which vegetation patterns were taken when running the BVOCEM standard run, simulates the global distribution of six plant function types in a similar dynamic manner. Crop functional types are not yet fully implemented into either DGVM, but effects of areas converted to agriculture or pastures on regional or global isoprene emissions can be estimated in a simplified manner by decreasing the fraction of potential natural vegetation per grid-cell based on presentday landcover products (Arneth et al., 2008b; Lathière et al., 2010). In the simulations shown here, both models were applied without crop correction; in future it is to be expected that crop biogeochemical cycles (including the trace gas emissions) will be accounted for in a way that is consistent with the carbon, water and nitrogen cycles already represented in the models (Arneth et al., 2010). In case of MEGAN, vegetation distribution and seasonal variation in leaf area index is fixed, and prescribed as a remotely-sensed product based on MODIS, and therefore includes representation of crop and natural vegetation (Guenther et al., 2006).

\subsection{Enabling transfer of input data between models}

Limits of standardising experiments between models are often reached rather quickly due to the inherent structural design of the individual models. This is particularly relevant when passing vegetation fields between models, which may require mapping of vegetation classes to PFTs and vice versa, and resultant adjustment of emission factors. In case of 
Table 1. List of simulations, described as "Model-climate-vegetation" (for example, MEGAN-CRU-LPJV is MEGAN model, run with CRU climate data and LPJ vegetation (and emission factors) and MEGAN algorithm) and MEGAN algorithm. Subscripts "d" and "f" indicate whether the DGVMs had dynamic vegetation enabled, or were driven by fixed vegetation fields.

\begin{tabular}{|c|c|c|c|}
\hline LPJ & MEGAN & BVOCEM & Simulation \\
\hline L1. LPJ-CRU-LPJV & M1. MEGAN-NCEP-MEGANV & B1. BVOCEM-UM-SDGVMV ${ }_{\mathrm{d}}$ & Standard model version \\
\hline L2. LPJ-NCEP-LPJV & M2. MEGAN-CRU-MEGANV & B2. BVOCEM-CRU-SDGVMV ${ }_{d}$ & $\begin{array}{l}\text { Change climate } \\
\text { compared to standard }\end{array}$ \\
\hline L3. LPJ-CRU-MEGANV & M3. MEGAN-NCEP-LPJV & $\begin{array}{l}\text { B3a. BVOCEM-CRU-MEGANV } \\
\text { B3b: BVOCEM-NCEP-MEGANV }\end{array}$ & $\begin{array}{l}\text { Change vegetation } \\
\text { compared to standard }\end{array}$ \\
\hline L4. LPJ-NCEP-MEGANV & M4. MEGAN-CRU-LPJV & B4. BVOCEM-CRU-LPJV & $\begin{array}{l}\text { Change climate and } \\
\text { vegetation compared to } \\
\text { standard. }\end{array}$ \\
\hline
\end{tabular}

SDGVM and LPJ-GUESS, vegetation dynamics, PFT distribution composition, and isoprene emissions are linked because each of these processes respond dynamically to climate. For LPJ-GUESS, experiments 2 to 4 either included prescribing vegetation cover from MODIS/MEGAN, or running with NCEP climate but keeping PFT distribution fixed from the CRU standard runs. This required the use of a version of LPJ-GUESS with its standard fast-exchange processes (photosynthesis, BVOC) enabled but with applying prescribed vegetation characteristics and soil, as well as adopting the MEGAN vegetation classes for use in LPJGUESS (Table A1). Since isoprene emissions are directly coupled to the model's carbon cycle simulations, parameters for the photosynthesis calculations were adopted for the MEGAN vegetation, primarily by applying the photosynthesis temperature limits from LPJ-GUESS's equivalent PFTs. Additionally, the average area-based emission factors applied in MEGAN (Guenther et al., 2006) had to be converted into leaf-based values used in LPJ-GUESS, taking into account the modelled specific leaf area (SLA, $\mathrm{m}_{\text {leaf }}^{2} \mathrm{~kg} \mathrm{C}^{-1}$ ) and the standard LAI used in MEGAN (5.0). This was based on the simple relationship $E_{L P J} / \mathrm{SLA} \cdot \operatorname{LAI}(5) \cdot 0.42=E_{\mathrm{MEGAN}}$; 0.42 is an empirical factor derived using a canopy environment model and represents the ratio of leaf- to canopy-scale emission factors for a canopy with an LAI of 5. The inverse equation was used to convert the LPJ leaf-level emission factors to canopy-scale emission factors. When running the BVOCEM with different vegetation classes, the emission factors had to be adapted to ensure consistency across the various PFTs and the units. For the experiments using either the SDGVM or the MEGAN vegetation patterns, globallyaveraged emission factors from Guenther et al. (2006) were used. When using vegetation input provided by LPJ, the LPJ emission factors were converted to the appropriate unit using the equation above.

\section{Results}

\subsection{Annual totals and geographical/seasonal patterns}

In their standard settings (LPJ-CRU-LPJV, MEGAN-NCEPMEGANV and BVOCEM-UM-SDGVMV) between-model variation in average global isoprene emissions was small, 378 to $496 \mathrm{Tg} \mathrm{Ca}^{-1}$ (Figs. 1, 2). Emissions for LPJ-GUESS were somewhat higher than reported in Arneth et al. (2007a; 463 vs. $410 \mathrm{Tg} \mathrm{C}^{-1}$ ), arising from the slightly different averaging period, small adjustments to the way seasonallychanging emission factors were calculated, and a newly introduced leaf-energy balance calculation (Schurgers et al., 2011). Likewise, for the BVOCEM simulations we removed the assumed $4 \%$ loss associated with within-canopy reactions in the reported $471 \mathrm{Tg} \mathrm{Ca}^{-1}$ (Lathière et al., 2010). The 22-yr averaged emissions for MEGAN $\left(378 \mathrm{Tg} \mathrm{Ca}^{-1}\right.$ ) were lower than reported by Guenther et al. (2006) for the year 2003 (ca. $530 \mathrm{Tg} \mathrm{Ca}^{-1}$ ). These, too, reflected the longer simulation period with a slightly cooler average temperature compared to 2003 alone as well as the exclusion of the soil moisture activity factor and differences in the version of NCEP temperature and solar radiation data used to drive the simulations shown here.

Figure 1 shows that all three models place the dominant emission source in tropical regions, especially South America and Africa, reflecting the year-long warm temperatures, high levels of radiation and relatively high emission potentials assigned to tropical vegetation (Guenther et al., 1995; Arneth et al., 2008a). Regional differences emerge clearly from the Figure, for instance in South America and Australia. Over the course of the year (Fig. 2a, e, i), emissions in the two latitudinal bands from the equator to 30 degrees north and south varied relatively little, in response to small seasonal changes in temperature and precipitation. Overall, BVOCEM simulations showed the largest seasonal variation in these regions, as well as the largest difference between Southern and Northern Hemisphere - irrespective of the climate used or the number of years averaged (Fig. 2i, j) - a 

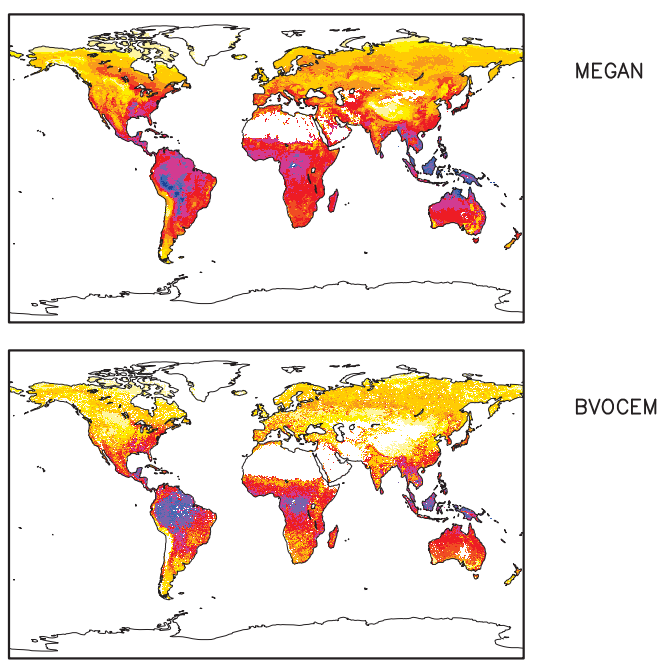

BVOCEM

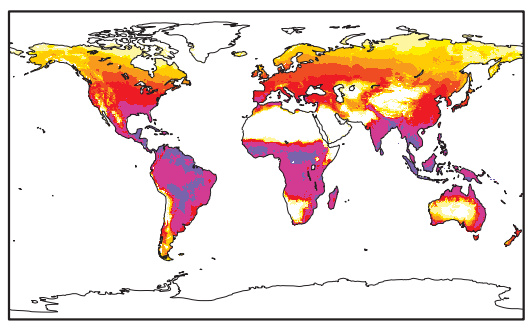

LPJ-GUESS

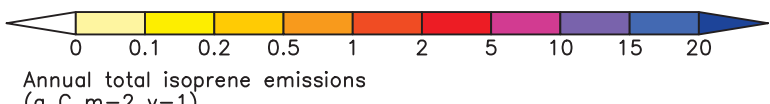

Annual total isoprene emissions
$(\mathrm{g} C \mathrm{C}-2 \mathrm{y}-1)$

Fig. 1. Average annual global isoprene emissions for the period 1981-2002 from three different emission models. Averages are from the "standard" model setups in the case of LPJ-GUESS and MEGAN (see Table 1, Fig. 2, panels a, e), and with CRU climate in the case of BVOCEM (Fig. 2, panel i).

feature that was reduced when MEGAN vegetation was applied (Fig. 2k). By contrast, in MEGAN and LPJ-GUESS, magnitude and seasonal variation in the northern and southern tropics ( 0 to 30 degrees) were very similar, the average sums for $-30^{\circ}$ to $+30^{\circ}$ differed by less than $20 \%$ between the two models. All three models simulate maximum emissions from the northern temperate zones $\left(30\right.$ to $\left.60^{\circ} \mathrm{N}\right)$ during the Northern Hemisphere summer months to be equal to emissions from either the northern or southern tropical regions.

\subsection{Effects of varying climate input}

In MEGAN and BVOCEM, changing climate affects emissions directly via the temperature- and light-driven emission algorithms, in the case of LPJ-GUESS the effects operate mainly via the temperature and light effects on electron transport rates, and the difference between the temperature optimum of electron transport and isoprene production. As seen in Fig. 2, in the two DGVMs, changing climate inputs also affected calculated emissions indirectly, by altering the distribution of PFTs, total leaf area and the seasonality of leaf growth (subscripts "d" in Fig. $2 b, j$ ). With dynamic vegetation enabled, applying a different climate changed annual emissions by $3 \%$ (LPG-GUESS; CRU to NCEP) and $10 \%$ (BVOCEM, UM to CRU).

When run with non-standard climate but unchanged vegetation as compared to standard runs, emissions increased notably in LPJ-GUESS (Fig. 2a, b) and decreased in MEGAN (Fig. 2e, f). The relative response when swapping NCEP and CRU in MEGAN and LPJ-GUESS, respectively, yielded an increase of close to $30 \%$ in LPJ-GUESS and a decrease by a little more than $10 \%$ in MEGAN. In both cases, applying the CRU climate resulted in lower emissions compared to runs that applied NCEP climate. By contrast, a simulation with BVOCEM and fixed vegetation (from MEGAN) yielded emissions higher by approximately $10 \%$ in the CRU compared to the NCEP simulation ( 269 vs. $244 \mathrm{Tg} \mathrm{Ca}^{-1}$; not shown).

Regionally, differences caused by change in climate input were even larger than indicated by the global sums, and more varied. Figure 3 shows the direct effects of differing climate datasets only (i.e. using fixed vegetation in all cases), BVOCEM exhibited uniformly higher rates of emissions for the CRU simulations compared to NCEP in large parts of the tropics, especially the rainforest regions, and slightly lower rates in savannas and some parts of the temperate forest regions. For LPJ-GUESS and MEGAN, emissions using NCEP versus CRU climate tended to be higher in a large part of the Northern Hemisphere temperate and boreal biome. Emissions were also enhanced in some parts of the tropical areas, but in other tropical regions this pattern was reversed especially in case of MEGAN. In LPJ-GUESS, lower emissions in the NCEP case were, for instance, calculated in northeastern and eastern South America, and parts of tropical Africa.

\subsection{Effects of a change in vegetation}

Alternating between the standard and an alternate vegetation dataset yielded substantially higher emissions in LPJGUESS (Fig. 2, panel c) and lower emissions in MEGAN (panel g). For BVOCEM, a change from MEGAN to LPJ vegetation reduced emissions, but to a much smaller degree compared to the other two models (panels k and 1 in Fig. 2). In the case of LPJ-GUESS, the change in vegetation led to a more pronounced seasonality in emissions in tropical regions of the Southern Hemisphere, whereas in MEGAN, this seasonality was substantially dampened compared to the standard model setup (panels e, g).

Changing vegetation affects emissions in several ways; the vegetation fields differ in their total LAI and seasonal phenology, and emission factors also need to be adjusted compared to the standard runs. Accordingly, Figure 4 shows a complex 

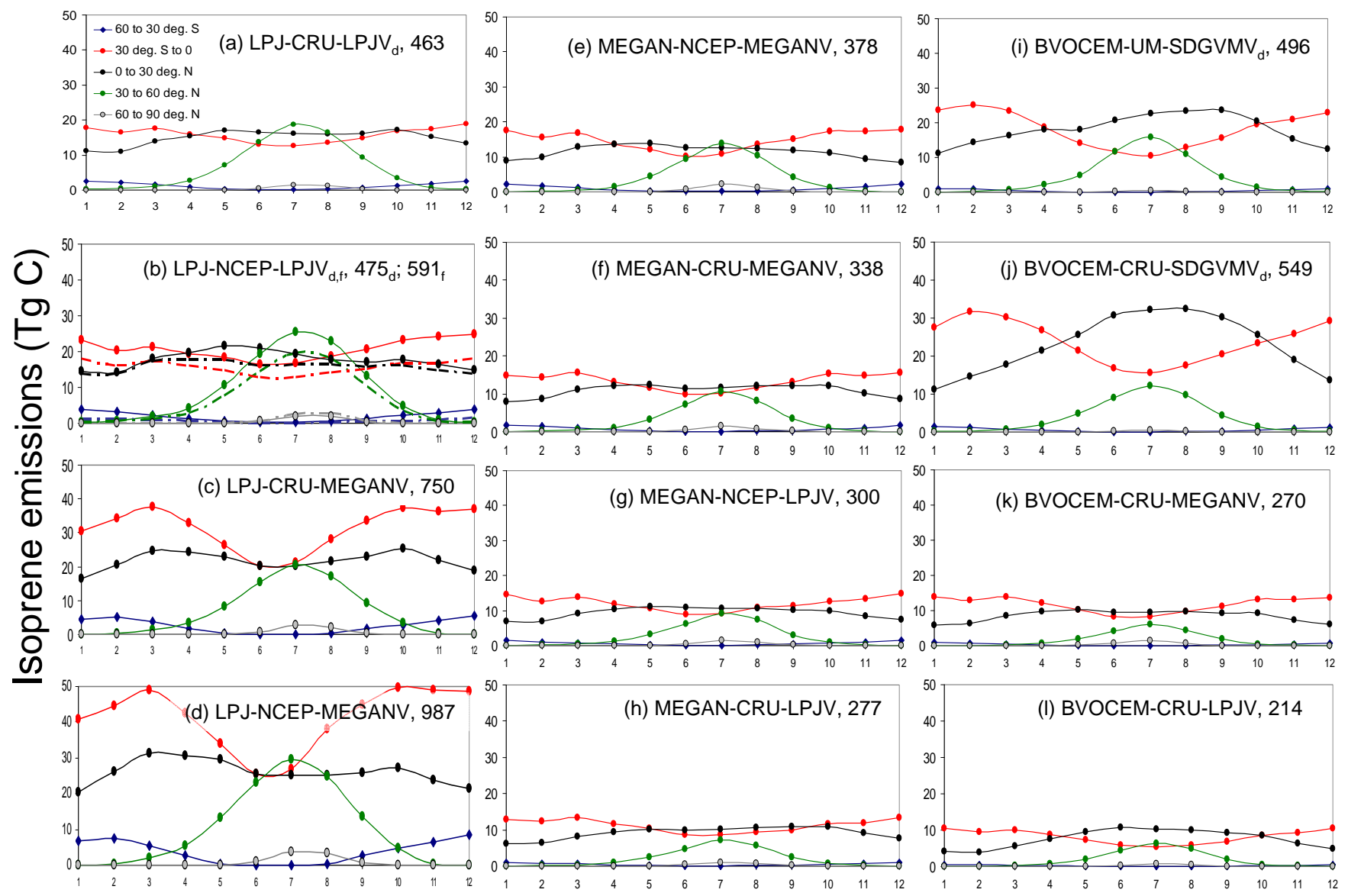

Month

Fig. 2. Seasonal isoprene emissions from the different model experiments, separated by latitudinal bands (deg.: degrees). The naming convention for each simulation was "Model-climate-vegetation" (see Table 1). Panels (a), (e) and (i) are equivalent to the models published and evaluated standard settings (e.g., Arneth et al., 2007a, Guenther et al., 2006, Lathière et al., 2010). Shown are averages for the period 1981-2002, except for panel (i) as the UM climate was only available for one year. Numbers in the top right corner of each panel are annual sums, in $\mathrm{Tg} \mathrm{Ca}^{-1}$. In panels $(\mathbf{a}, \mathbf{b})$ and $(\mathbf{i}, \mathbf{j})$, For the two DGVMs, subscribed "d" or " $\mathrm{f}$ " indicates whether the dynamic vegetation core in the model responds to the climate in the given simulation (dash-dotted line in panel (b)), or whether vegetation prescribed from the standard run was used (straight line in panel (b)).

pattern when the simulation results are plotted in their geospatial and temporal distribution. Only few responses were uniform in all three models when switching from MEGAN to LPJ vegetation. Simulations with MEGAN vegetation appear to generally yield higher emissions in large parts of Australia, southern Africa, tropical rain forest regions and, during the Northern Hemisphere summer months, large parts of the boreal biome. In contrast, lower emissions are simulated from the South American savanna (cerrado) regions and parts of the African savannas, and in LPJ-GUESS and BVOCEM, temperate regions in Europe, Asia and the US. For most other regions the model response was varied with no obvious similarities with respect to the direction of the change introduced by vegetation.

\subsection{Combination of effects}

As seen in Fig. 1, the effects of combined climate and vegetation changes compared to the standard run were larger than for single changes for all models. For MEGAN, when applying the CRU climate together with LPJ-GUESS vegetation, emissions were reduced to $70 \%$ of its standard setup, whereas in LPJ-GUESS the combined NCEP climate and MEGAN vegetation increased emissions by more than a factor of two (Fig. 1, panels d, h). For BVOCEM, the change from using UM to CRU climate increased annual totals by $10 \%$, but with the combination of CRU climate along with MEGAN and LPJ fixed vegetation, emissions decreased to approximately 50 and $40 \%$ of the SDGVM-vegetation simulation, respectively (Fig. 1, panels j-1). Particularly notable are the much enhanced seasonal amplitudes in the southern 
DJF

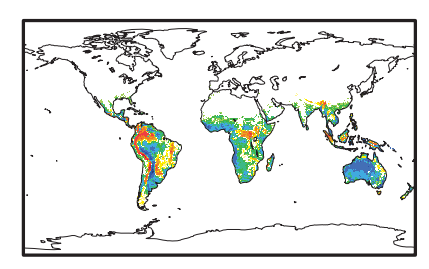

MAM

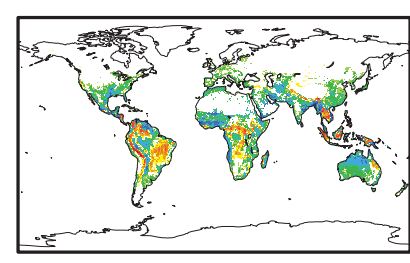

JJA

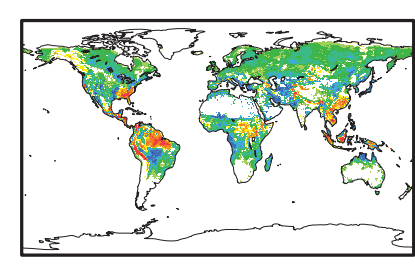

SON

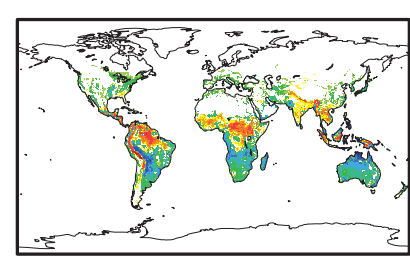

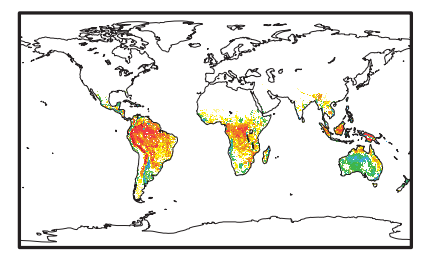
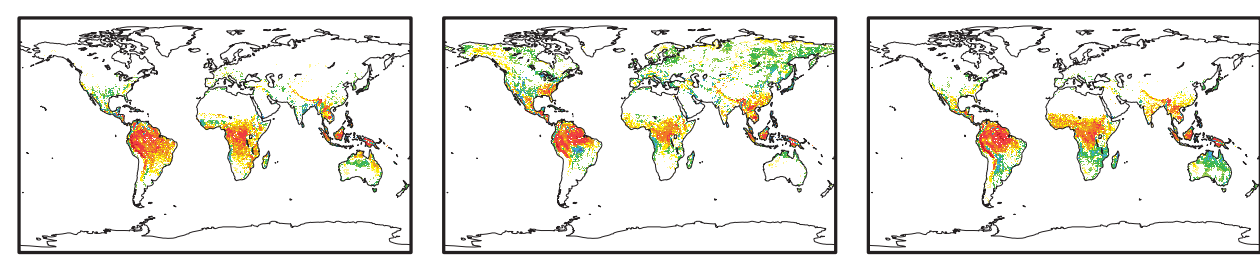

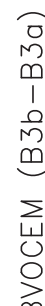
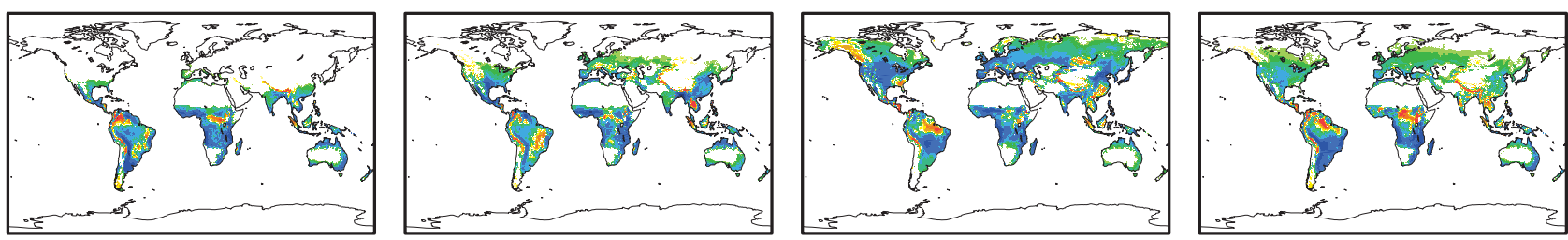

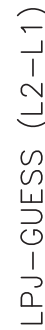

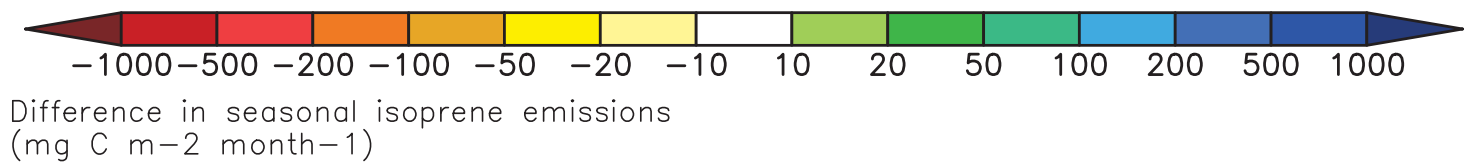

Fig. 3. Difference in isoprene emissions $\left(\mathrm{mg} \mathrm{C} \mathrm{m}^{-2} \mathrm{month}^{-1}\right)$ for simulations performed with NCEP climate minus simulations with CRU climate (top: M1-M2; middle: B3b-B3a; bottom: L2-L1; see Table 1). In the case of the dynamic vegetation models, the differences shown are those with fixed vegetation $\left(\mathrm{L} 2: \mathrm{LPJV}_{f}\right)$; and in case of BVOCEM, MEGAN vegetation was applied. Panels show monthly averages over three-month periods December to February (DJF); March to May (MAM); June to August (JJA); September to November (SON).

tropics when using LPJ together with MEGAN vegetation as well as NCEP climate. For BVOCEM-CRU runs, applying fixed vegetation greatly dampened the seasonality both in southern and northern tropics compared to runs where vegetation responded dynamically to seasonal climate.

\subsection{Interannual variability}

In their dynamic vegetation configuration, interannual variability of normalised and detrended annual isoprene emissions was found for both LPJ-GUESS and BVOCEM to be larger in the high northern latitudes than in any other of the latitude bands, varying by up to $15 \%$ (Fig. 5). In the other regions, maximum between-year variability in emission rates was around 5\% in LPJ-GUESS, and around 10\% in BVOCEM. A clear linear relationship between the annual isoprene emission rate output of the two models emerged, but with a distinctly different slope for the latitudinal band 60 $90^{\circ} \mathrm{N}$ (1.06) and the other regions (c. 0.4, Fig. 5, inset). The close relationship between the two models, occurring despite different isoprene algorithms, emission capacities and simulated vegetation patterns suggests on a decadal perspective a mostly climate-driven variability in isoprene emissions from one year to the next, since the models were driven by the same climate in these experiments (CRU).

When investigating single climatic drivers for the regions in the bands from $30^{\circ} \mathrm{S}$ to $60^{\circ} \mathrm{N}$, relatively weak linear relationships were found with temperature in the period JuneJuly-August, with $r^{2}$ values of a linear regression ranging from 0.3 to 0.6 (not shown); similarly neither temperatures in December- February nor annual precipitation had any predictive strength. Variability in weather affects emission rates not only directly but also via changes in rates of photosynthesis and the amount of emitting green tissues. For LPJ-GUESS, 
DJF
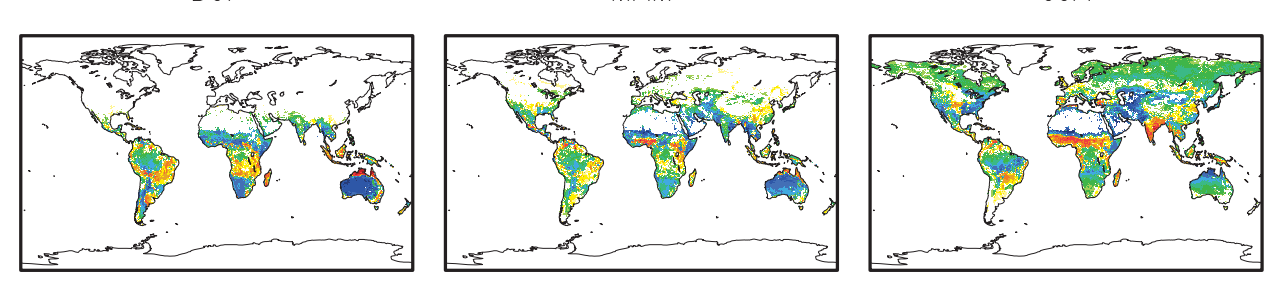

JJA
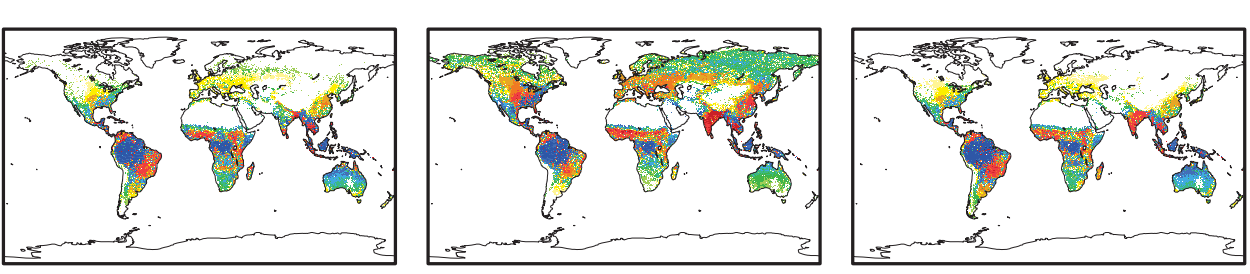

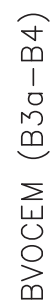
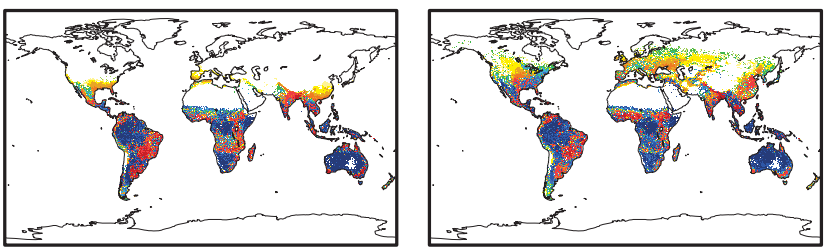
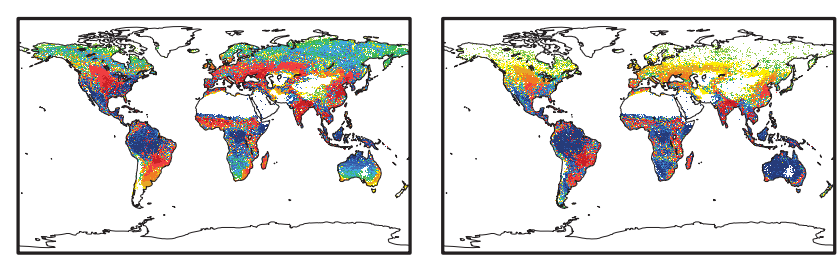

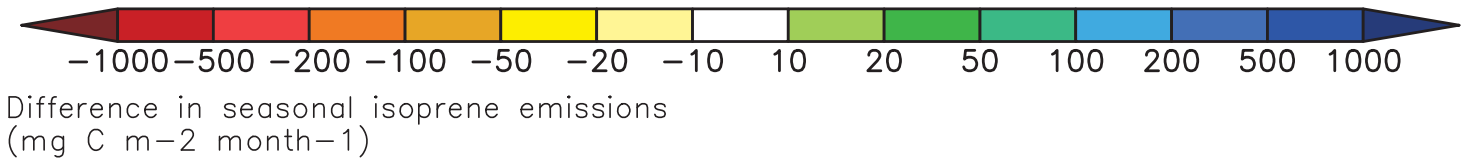

Fig. 4. Difference in isoprene emissions $\left(\mathrm{mg} \mathrm{C} \mathrm{m}^{-2} \mathrm{month}^{-1}\right)$ for simulations performed with MEGAN vegetation minus LPJ-GUESS vegetation. Panels show monthly averages over three-month periods, the same as those in Fig. 3 (top: M1-M3; middle: B3a-B4; bottom: L3-L1, see Table 1).

where isoprene production is closely linked to photosynthesis, interannual variability in gross primary productivity (GPP) was somewhat larger (standard deviation around the mean was up to $\sim 10 \%$, for the normalised and detrended data) than for isoprene, and with the exception of the northernmost band, no common patterns emerged between variability in isoprene and that in GPP. For BVOCEM, where emissions scale directly with leaf area index, rather than with primary productivity, interannual variability in LAI of the chief emitting PFTs was of the same magnitude than for isoprene, but here, too, a relationship between variation in LAI and that in isoprene was only notable for the 60 to $90^{\circ} \mathrm{N}$ band, as well as (but weaker) for the regions between 30 and $60^{\circ} \mathrm{N}$ (not shown).

\section{Discussion}

Comparing the three models in their published standard versions confirms previous global simulations in that the global isoprene source is clearly dominated by the tropical regions (see Guenther et al., 1995; Arneth et al., 2008a, and references therein). The standard versions monthly emission rates varied between ca. 10 and $25 \mathrm{TgC}$ in the two bands bound by 30 degrees latitude north and south of the equator. The three models also simulated seasonal maxima in northern temperate regions that were of the same magnitude as in the tropics. Annual global emission totals were within the range of previously published studies, with MEGAN being somewhat lower than what is typically found in bottom-up global models (Arneth et al., 2008a).

Between-model discrepancies emerged regarding the magnitude of the seasonal cycle in the southern and northern tropics. Seasonal variation by a factor of approximately 2 for a 


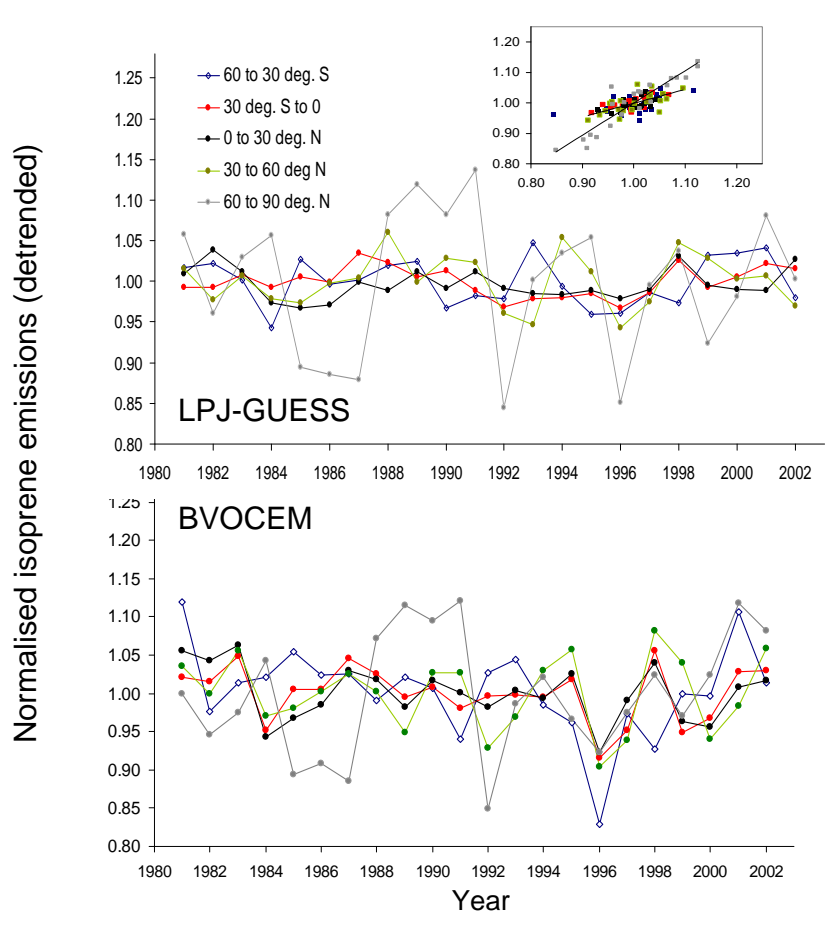

Fig. 5. Annual total emissions from LPJ-GUESS (top panel) and BVOCEM (bottom panel), separated by latitudinal band, over the 22-yr simulation period. Simulations were performed by applying the CRU climate and with dynamic vegetation features enabled. $\mathrm{CO}_{2}$ concentration affected vegetation productivity, but the direct effects of $\mathrm{CO}_{2}$ on isoprene production were disabled. Data were normalised to unity by the average emission rate over the simulation period, and a linear trend was removed. The inset shows the correlation between the two models, with a separate regression for the northernmost latitudinal band $\left(60-90^{\circ} \mathrm{N}\right.$, grey).

tropical gridcell located in the Amazon has also been found in a simulation by Levis et al. (2003), who simulated the seasonal emission maximum around February-March and a second, smaller peak around July-August. Emission minima occurred around months 6 and 11. Satellite-retrieved formaldehyde (HCHO) concentrations indicated minima in $\mathrm{HCHO}$ concentrations above the Amazon from April to June, corresponding with the transition period between the wet and the dry season (Barkley et al., 2008, 2009). As HCHO is a principal atmospheric isoprene oxidation product, these patterns have been interpreted as a seasonal isoprene emission low, arising from a lag between substantial new leaf area growth (which takes place during that period of the year and continues well into the dry season; Huete et al., 2006; Myneni et al., 2007) and the delayed onset of isoprene emission in newly-developed leaves. However, in warm growth environments, the period between onset of photosynthesis and isoprene emissions in newly-emerging foliage has been found to be short (Kuhn et al., 2004; Wiberley et al., 2005), lags on the order of weeks may thus be difficult to fully reconcile with the process of leaf growth alone.

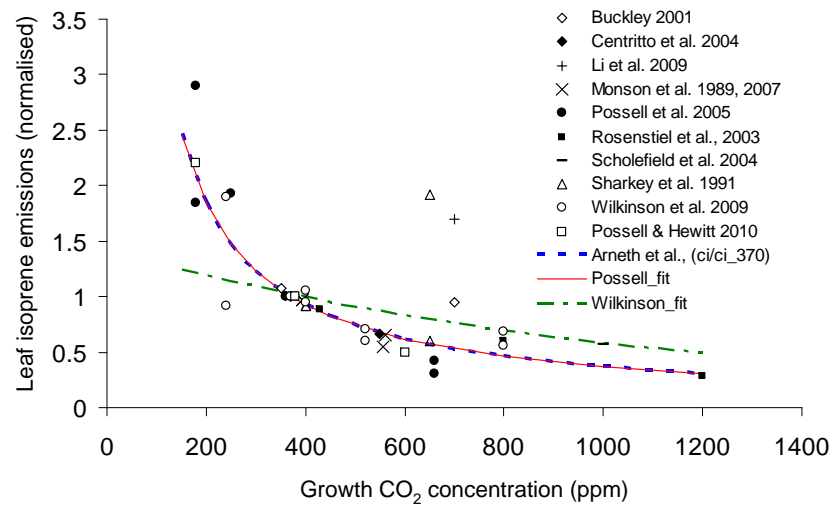

Fig. 6. Leaf-level response of isoprene emissions to varying $\mathrm{CO}_{2}$ growth environment. Symbols represent observations from a number of studies and plant species, and are normalised to be unity at growth $\mathrm{CO}_{2}$ concentration $\left(C_{a}\right)$ of $c 370 \mathrm{ppm}$. Data shown are only from emission measurements that were undertaken at the $\mathrm{CO}_{2}$ growth concentration. The lines represent three different algorithms that are currently being applied to represent the observed response in global models: (i) the empirical function proposed by Possell et al. (2005), used e.g., for BVOCEM in (Lathière et al., 2010); (ii) a function representing the ratio of change in (non water-stressed) leaf-internal $\mathrm{CO}_{2}$ concentration $\left(C_{i}\right)$ to $C_{i}$ at $370 \mathrm{ppm}$, used e.g., for LPJ-GUESS in $\left(C_{i} / C_{i-370}\right.$; Arneth et al., 2007a), which can be interpreted as reflecting the varying leaf-internal competition for $\mathrm{CO}_{2}$ (Rosenstiel et al., 2004) - this line is by chance nearly identical to the empirical function in (i); (iii) a "Hill"-type function proposed by Wilkinson et al. (2009), with $C_{i}$ estimated as $0.7 \times C_{a}$ in analogy to the same assumption applied in LPJ-GUESS (Arneth et al., 2007b). Approach (iii) has been adopted for MEGAN e.g., in Heald et al. (2009). The Figure is adapted from Young et al. (2009), and updated with latest published observations.

In Fig. 2, latitudinal and longitudinal averaging blurs some features that may be typical for the Amazon with that of other tropical regions, and the simulated patterns thus do not show clearly-defined emission maxima during the dry season in the Southern Hemisphere tropics (Barkley et al., 2009). Still, the calculated seasonal variation appears reasonable when compared to the limited number of canopy-scale measurements from the tropical regions which have demonstrated similar or even much larger differences between emission minima and maxima throughout the year (Karl et al., 2004, 2007; Muller et al., 2008), and is, in the model simulations, related to combination of variation in leaf area index, incident radiation and air temperature.

The observed response to changing some of the main driver components of the models was complex, and points to substantial uncertainty in modelled biogenic emission patterns that can be introduced solely by applying different present-day global climate or vegetation products. Moreover, the direction of the simulated emission changes was not as uniform as anticipated. The CRU climate, for instance, tends to be warmer compared to the NCEP reanalysis, with a global 
temperature difference of approximately $0.8 \mathrm{~K}$ averaged over our simulation period, especially in the tropical regions. This gives rise to expectations that emissions would decrease in experiments that move from CRU to NCEP climate, and vice versa. But this response was only observed in the BVOCEM (using fixed MEGAN vegetation) simulation.

The NCEP climate product tends to be wetter in some regions when compared with CRU. In LPJ-GUESS, increased precipitation in dry regions would stimulate rates of photosynthesis (Schaphoff et al., 2006) and hence isoprene production, which could contribute to enhanced emissions. When vegetation responds dynamically to the NCEP climate, an additional influence is via changes in the PFT distribution, which in the tropical areas was shifted towards the evergreen type in the NCEP simulations, with lower emission capacities compared to raingreen vegetation (not shown). Such a vegetation shift compensates for the climate effects to some degree, since the evergreen PFT has a lower emission capacity compared to tropical raingreen vegetation (Arneth et al., 2007a).

Finally, a third confounding factor could be radiation levels. In the CRU product, radiation is given as percent cloudiness, which can be transformed into incident solar radiation as a function of solar angle, shortwave albedo and clear sky atmospheric transmissivity (Monteith and Unsworth, 1990). The resulting insolation was lower than in the NCEP product (not shown) and is probably a chief driver behind the increase of emissions in LPJ-GUESS + NCEP, as well as the lower annual emissions in MEGAN+CRU compared to their respective standard cases. Previous calculations using the MEGAN standard case but with CRU climate also led to reductions of approximately similar magnitude than here $(-11 \%$; Guenther et al., 2006). This smaller sensitivity was caused by taking a different approach to convert CRU cloud cover into irradiance levels, based on the BEIS inventory-model algorithms (Pierce et al. 1998), as well as from different time averaging for the comparison which was based on a single year (2003). Overall, the multifaceted interactions between varying temperatures, radiation and precipitation highlight why a simple extrapolation to expected emission changes under future or past climate changes, based on the models' responses for present-day, would be problematic.

LPJ-GUESS tends to simulate lower LAI in most parts of Australia and southern Africa compared to the MODIS product used in MEGAN (see e.g., Sitch et al., 2003; Guenther et al., 2006), which can explain the model-to-model differences in these regions seen in Fig. 4. Moreover, changing from MEGAN vegetation to LPJ vegetation also meant a change from accounting for crops to potential natural vegetation, hence the lower emission rates in parts of Europe, Asia and the U.S. calculated by LPJ GUESS and BVOCEM when applying MEGAN vegetation. Lathière et al. (2010) found global crop area to cause a $15 \%$ reduction of emissions in late 20th century isoprene emissions compared to a simulation with potential natural vegetation, and by ca. 30 to $40 \%$ in northern America and Europe, respectively. In an LPJ-GUESS simulation for Europe, emissions after accounting for crop area were reduced by more than a factor of three (Arneth et al., 2008b). At the same time, changes in PFT distribution and emission factors also play an important role in the interpretation of the observed between-model responses to variable vegetation. For instance, MEGAN assigns large parts of Australia to be covered by shrubs with high emission potentials (Guenther et al., 2006), while LPJ-GUESS simulates these areas to be dominated by grassland rather than woody vegetation (Sitch et al., 2003) that has a much lower emission potential.

The boreal forest regions, where all models respond with a decrease in emissions when applying LPJ vegetation compared to MEGAN vegetation have a large component of fineleaf evergreen and shrub vegetation in MEGAN, and a mix of broadleaf deciduous and evergreen conifers as well as (in Eastern Siberia) deciduous conifers in LPJ-GUESS. The decrease is hence mainly to be interpreted in view of the emission capacities since, after conversion to common units, only the boreal broadleaf summergreen PFTs had higher emission factors compared to shrubs and fineleaf PFTs. Pfister et al. (2008) examined the sensitivity of MEGAN to land cover inputs using three different sets of satellite-derived LAI and PFT datasets and reported a factor of 2 or more difference on global to regional scales. This analysis highlights the uncertainties in land-cover estimates, affecting emission capacities as well as also canopy structural properties, and continued improvements in these data will eventually lead to more accurate emission estimates.

Interannual variability in emission rates was found to be small, except for the northernmost latitudinal band, where emissions are very low in absolute terms. Although some of the anomalies (i.e., the low rates in 1992) corresponded to climate fluctuations (i.e., cool summer temperatures following the Mount Pinatubo eruption, and subsequent effects on emissions; (Lucht et al., 2002; Telford et al., 2010)) the variation in precipitation and temperature for regions between 60 to $90^{\circ} \mathrm{N}$ were not substantially larger than in the other latitude bands, and the magnitude of the interannual variation hence cannot be directly attributed to larger climate fluctuations in that region. Considering both regional and interannual variability, fluctuations of typically not more than 5 and (exceptional) $10 \%$ around the mean have also been found for simulated isoprene emissions when applying the DGVM ORCHIDEE for the period 1983 to 1995 (Lathière et al., 2006).

Correlations between simulated emission rates and LAI, GPP and weather are to be expected since these are main drivers of the underlying algorithms and affect emissions on time-scales of minutes to weeks, and hence should also hold over the course of a few years. For the two dynamic vegetation models in our study, no single factor emerged as a clear driver of interannual variation, suggesting compensating processes that modify the overall response. This may 
initially seem counterintuitive, as for instance warm weather conditions that foster isoprene emissions should also enhance GPP and LAI - by lengthening growing season or by being closer to the temperature-optimum for photosynthesis. But warm temperatures can also coincide with soil-water deficit, thereby reducing GPP and LAI, or, especially in tropical and subtropical regions, exceeding optimal photosynthetic temperatures. Moreover, computing annual averages across latitudinal bands can hide regionally-variable patterns that might otherwise reveal how weather and emissions covary (Lathière et al., 2006). Better understanding of how the various environmental factors and the associated vegetation growth responses interact would require flux sites where isoprene fluxes are measured over a number of years alongside ecosystem-atmosphere $\mathrm{CO}_{2}$ exchange measurements, but we are only aware of one such data set (Pressley et al., 2005) with four years of measurements. Interannual variability reported at this site, an aspen- and red oak-dominated hardwood forest, was less than $10 \%$.

\subsection{Short-term vs. long-term emission patterns}

The strong temperature-sensitivity of leaf emissions and anticipated warmer temperatures in a high- $\mathrm{CO}_{2}$ world have been the chief argument for assuming a greatly enhanced future isoprene source in simulations of future trace gas composition (e.g., Sanderson et al., 2003; Hauglustaine et al., 2005; Young et al., 2009). Increased atmospheric $\mathrm{CO}_{2}$ levels also enhance rates of leaf photosynthesis. It is expected that this $\mathrm{CO}_{2}$ fertilisation will sustain an enhanced vegetation productivity, even though acclimation processes on leaf- and canopy-scales, as well as nutrient or water limitations, may reduce the overall vegetation growth effects to below what is extrapolated from short-term leaf-level observations alone (Körner, 2006; Finzi et al., 2007; Hickler et al., 2008). The concomitant LAI increase would foster heightened isoprene emissions compared to present-day in addition to a direct temperature effect. However, an increasing number of studies have also shown a direct $\mathrm{CO}_{2}$ - effect on isoprene emissions, such that leaf emissions decline at above-ambient $\mathrm{CO}_{2}$ levels, possibly due to leaf-internal competition for some isoprene precursor substances (Rosenstiel et al., 2003; Possell et al., 2005; Wilkinson et al., 2009). Here, too, some compensatory effects can be detected, such that the response to varying $\mathrm{CO}_{2}$ differs depending on whether leaf area or mass is used as the reference, or whether leaf or whole plant emissions are being considered (Possell et al., 2005; Possell and Hewitt, 2010).

Global isoprene models are beginning to include a direct $\mathrm{CO}_{2}$-leaf emission response, adopting different algorithms that are summarised in Fig. 6 (Arneth et al., 2007a; Heald et al., 2009; Lathière et al., 2010; Pacifico et al., 2011). In future scenarios, accounting for $\mathrm{CO}_{2}$ inhibition has been shown to decrease emissions notably (several 10 s of a percent compared to present-day) in simulations that kept vegetation fixed. The overall reduction depends on both the choice of the $\mathrm{CO}_{2}$ scenario and the magnitude of temperature increase (Heald et al., 2009; Arneth et al., 2007a). Including the additional effects of a dynamic vegetation response combines effects of altered productivity as well as changing vegetation PFT mixtures on global emissions, which makes betweenstudy comparisons difficult. After accounting for the additional direct $\mathrm{CO}_{2}$ inhibition effect, the projected emission increase in response to warmer temperatures and enhanced leaf area was either reduced (applying MEGAN in the Community Land Model, and for the IPCC SRES scenario A1B; Heald et al., 2009), or emissions were close to present-day rates (range of SRES and climate models; Arneth et al., 2007a). In these two studies, global average LAI was modelled to increase more than three-fold (Heald et al., 2009), vs. by between 2 and $27 \%$ (Arneth et al., 2007a). Though LAI is not the sole factor explaining the diverging between-model responses to climate and $\mathrm{CO}_{2}$ change, these differences in LAI highlight the equal importance of developing robust projections of vegetation response to environmental changes in addition to improving process-based leaf-level isoprene algorithms. Assessments of future levels of air pollution and climate change respond sensitively to variation in future isoprene emissions (Sanderson et al., 2003; Hauglustaine et al., 2005; Young et al., 2009). A full and internally-consistent accounting of the suite of environmental and direct (i.e., land use/land cover change; Arneth et al., 2008b; Lathière et al., 2006, 2010) anthropogenic drivers that affect biogenic emissions, together with an accurate understanding of the manifold interactions and impacts caused by each of these drivers hence is necessary.

\section{Conclusion}

When applied in their standard setup, today's global isoprene emission models agree on important features regarding global emission totals, spatial distribution, seasonality and interannual variability. However, the simulated annual total emissions react sensitively to changes in one or more of the main model drivers, like vegetation fields or climate inputs. Moreover, "swapping" standard inputs introduces large changes in the simulated seasonality of emission patterns which can lead to either a strong dampening or substantial exaggeration of the observed seasonal cycles, especially in the tropics. Based on the limited published studies to date that examined seasonal emissions in tropical regions neither the absence of seasonally-varying emissions nor a hugely pronounced amplitude seem realistic. When incorporating isoprene emission modules into coupled chemistry-climate models it is thus advisable to check not only for annual total emission patterns but also for seasonal patterns - the uncritical incorporation of individual model components into larger framework should be avoided. 


\section{Appendix A}

Table A1. Use of plant functional types and isoprene emission factors for simulations in this study (dm: dry matter).

\begin{tabular}{|c|c|c|c|c|c|c|c|c|}
\hline $\begin{array}{l}\text { LPJ-GUESS } \\
\text { PFTs }\end{array}$ & Abbrev. & $\begin{array}{l}\text { Emission factor } \\
\left(\mu g \mathrm{Cg}^{-1}\right. \\
\left.\operatorname{leaf}_{\mathrm{dm}} \mathrm{h}^{-1}\right)\end{array}$ & $\begin{array}{l}\text { Emission factor } \\
\left(\mathrm{mg} \mathrm{C}^{-2}\right. \\
\left.\text { ground } \mathrm{h}^{-1}\right) \\
\text { for the BVOCEM } \\
\text { running with LPJ } \\
\text { vegetation }\end{array}$ & $\begin{array}{l}\text { MEGAN } \\
\text { PFTs }\end{array}$ & Abbrev. & LPJ assigned & $\begin{array}{l}\text { BVOCEM- } \\
\text { SDGVM PFTs }\end{array}$ & $\begin{array}{l}\text { Emission factor } \\
\left(\mathrm{mg} \mathrm{Cm}^{-2}\right. \\
\left.\text { ground } \mathrm{h}^{-1}\right) \\
\text { for the BVO- } \\
\text { CEM } \\
\text { running with } \\
\text { SDGVM } \\
\text { vegetation }\end{array}$ \\
\hline $\begin{array}{l}\text { 1. Tropical } \\
\text { Broadleaved } \\
\text { Evergreen }\end{array}$ & TrBE & 24.0 & 4.6 & $\begin{array}{l}\text { 1. Broadleaf } \\
\text { trees }\end{array}$ & btr & $1,2,4,5$ and 8 & 1. C3 grass & 0.4 \\
\hline $\begin{array}{l}\text { 2. Tropical } \\
\text { Broadleaved } \\
\text { Raingreen }\end{array}$ & TrBR & 45.0 & 4.6 & $\begin{array}{l}\text { 2. Fineleaf } \\
\text { trees }\end{array}$ & $\mathrm{ftr}$ & 3,6 and 7 & 2. $\mathrm{C} 4$ grass & 0.4 \\
\hline $\begin{array}{l}\text { 3. Temperate } \\
\text { Needleleaved } \\
\text { Evergreen }\end{array}$ & TeNE & 16.0 & 3.1 & $\begin{array}{l}\text { 3. Grass and } \\
\text { herbaceous }\end{array}$ & grs & 9 and 10 & $\begin{array}{l}\text { 3. Evergreen } \\
\text { broadleaf trees }\end{array}$ & 11.1 \\
\hline $\begin{array}{l}\text { 4. Temperate } \\
\text { Broadleaved } \\
\text { Evergreen }\end{array}$ & TeBE & 24.0 & 3.4 & 4. Shrubs & $\operatorname{shr}$ & $\begin{array}{l}\text { Adapted from } \\
1,2,4,5 \text { and } 8\end{array}$ & $\begin{array}{l}\text { 4. Evergreen } \\
\text { Needleleaf trees }\end{array}$ & 1.8 \\
\hline $\begin{array}{l}\text { 5. Temperate } \\
\text { Broadleaved } \\
\text { Summergreen }\end{array}$ & TeBS & 45.0 & 4.6 & $\begin{array}{l}\text { 5. Herbaceous } \\
\text { and shrubby crops }\end{array}$ & crp & $\begin{array}{l}\text { Adapted from } \\
9 \text { and } 10\end{array}$ & $\begin{array}{l}\text { 5. Deciduous } \\
\text { broadleaf trees }\end{array}$ & 11.1 \\
\hline $\begin{array}{l}\text { 6. Boreal } \\
\text { Needleleaved } \\
\text { Evergreen }\end{array}$ & BNE & 8.0 & 1.5 & & & & $\begin{array}{l}\text { 6. Deciduous } \\
\text { needleleaf trees }\end{array}$ & 0.6 \\
\hline $\begin{array}{l}\text { 7. Boreal } \\
\text { Needleleaved } \\
\text { Summergreen }\end{array}$ & BNS & 8.0 & 0.8 & & & & & \\
\hline $\begin{array}{l}\text { 8. Boreal } \\
\text { Broadleaved } \\
\text { Summergreen }\end{array}$ & BBS & 45.0 & 4.6 & & & & & \\
\hline 9. C3 herbaceous & $\mathrm{C} 3$ & 16.0 & 1.6 & & & & & \\
\hline 10. $\mathrm{C} 4$ herbaceous & $\mathrm{C} 4$ & 8.0 & 0.82 & & & & & \\
\hline
\end{tabular}

Acknowledgements. This work was supported by a Human Frontier Science Programme grant to AA, and contributes to the EU FP7 IP PEGASOS (FP7-ENV-2010/265148). AA and GS acknowledge additional support from the Swedish Research Councils Formas (2007-331) and VR (2005-4039; 2009-4290), and from an Alexander von Humboldt Foundation Guest-Fellowship to AA at IMK-IFU. The BVOCEM development was part of the UK Natural Environment Research Council's Quantifying and Understanding the Earth System (QUEST) Research Programme (grant NE/C001621/1).

Edited by: J. Rinne

\section{References}

Arneth, A., Miller, P. A., Scholze, M., Hickler, T., Schurgers, G., Smith, B., and Prentice, I. C.: $\mathrm{CO}_{2}$ inhibition of global terrestrial isoprene emissions: Potential implications for atmospheric chemistry, Geophys. Res. Lett., 34, L18813, doi:10.11029/12007GL030615, 2007a.

Arneth, A., Niinemets, U., Pressley, S., Bäck, J., Hari, P., Karl, T., Noe, S., Prentice, I. C., Serca, D., Hickler, T., Wolf, A., and Smith, B.: Process-based estimates of terrestrial ecosystem isoprene emissions: incorporating the effects of a di- rect $\mathrm{CO}_{2}$-isoprene interaction, Atmos. Chem. Phys., 7, 31-53, doi:10.5194/acp-7-31-2007, 2007b.

Arneth, A., Monson, R. K., Schurgers, G., Niinemets, U., and Palmer, P. I.: Why are estimates of global isoprene emissions so similar (and why is this not so for monoterpenes)?, Atmos. Chem. Phys., 8, 4605-4620, doi:10.5194/acp-8-4605-2008, 2008a.

Arneth, A., Schurgers, G., Hickler, T., and Miller, P. A.: Effects of species composition, land surface cover, $\mathrm{CO}_{2}$ concentration and climate on isoprene emissions from European forests, Plant Biol., 10, 150-162, doi:110.1055/s-2007-965247, 2008b.

Arneth, A., Sitch, S., Bondeau, A., Butterbach-Bahl, K., Foster, P., Gedney, N., de Noblet-Ducoudre, N., Prentice, I. C., Sanderson, M., Thonicke, K., Wania, R., and Zaehle, S.: From biota to chemistry and climate: towards a comprehensive description of trace gas exchange between the biosphere and atmosphere, Biogeosciences, 7, 121-149, doi:10.5194/bg-7-121-2010, 2010.

Ashworth, K., Wild, O., and Hewitt, C. N.: Sensitivity of isoprene emission estimated using MEGAN to the time resolution of input climate data, Atmos. Chem. Phys., 10, 1193-1201, doi:10.5194/acp-10-1193-2010, 2010.

Atkinson, R.: Atmospheric chemistry of VOCs and $\mathrm{NO}_{\mathrm{X}}$, Atmos. Environ., 34, 2063-2101, 2000.

Barkley, M. P., Palmer, P. I., Kuhn, U., Kesselmeier, J., Chance, K., Kurosu, T. P., Martin, R. V., Helmig, D., and Guenther, A.: 
Net ecosystem fluxes of isoprene over tropical South America inferred from GOME observations of HCHO columns, J. Geophys. Res., 113, D20304, doi:10.21029/22008jd009863, 2008.

Barkley, M. P., Palmer, P. I., De Smedt, I., Karl, T., Guenther, A., and Van Roozendael, M.: Regulated large-scale annual shutdown of Amazonian isoprene emissions?, Geophys. Res. Lett., 36, L04803, doi:10.01029/02008GL036843, 2009.

Barkley, M. P., Palmer, P. I., Ganzeveld, L., Arneth, A., Hågberg, D., Karl, T., Guenther, A., Paulot, F., Wennberg, P. O., Mao, J., Kurosu, T. P., Chance, K., Muller, J.-F., De Smedt, I.,Van Roozendael, M., Chen, D., Wang, Y., and Yantosca, R. M.: Can a 'state of the art' chemistry transport model simulate Amazonian tropospehric chemistry?, J. Geophys. Res., accepted, 2011.

Beerling, D. J. and Woodward, F. I.: Vegetation and the terrestrial carbon cycle. Modelling the first 400 Million years, Cambridge University Press, Cambridge, UK, 2001.

Buckley, P. T.: Isoprene emissions from a Florida scrub oak species grown in ambient and elevated carbon dioxide, Atm. Env., 35, 631-634, 2001.

Centritto, M., Nascetti, P., Petrilli, L., Raschi, A., and Loreto, F.: Profiles of isoprene emission and photosynthetic parameters in hybrid poplars exposed to free-air $\mathrm{CO}_{2}$ enrichment, Plant Cell Environ., 27, 403-412, 2004.

Claeys, M., Graham, B., Vas, G., Wang, W., Vermeylen, R., Pashynska, V., Cafmeyer, J., Guyon, P., Andreae, M. O., Artaxo, P., and Maenhaut, W.: Formation of secondary organic aerosols through photooxidation of isoprene, Science, 303, 1173-1176, 2004.

Finzi, A. C., Norby, R. J., Calfapietra, C., Gallet-Budynek, A., Gielen, B., Holmes, W. E., Hoosbeek, M. R., Iversen, C. M., Jackson, R. B., Kubiske, M. E., Ledford, J., Liberloo, M., Oren, R., Polle, A., Pritchard, S., Zak, D. R., Schlesinger, W. H., and Ceulemans, R.: Increases in nitrogen uptake rather than nitrogenuse efficiency support higher rates of temperate forest productivity under elevated $\mathrm{CO}_{2}$, Proc. Natl. Acad. Sci., 104, 1401414019, doi:10.1073/pnas.0706518104, 2007.

Gerten, D., Schaphoff, S., Haberlandt, U., Lucht, W., and Sitch, S.: Terrestrial vegetation and water balance - hydrological evaluation of a dynamic global vegetation model, J. Hydrol., 286, 249-270, 2004.

Guenther, A., Monson, R. K., and Fall, R.: Isoprene and monoterpene emission rate variability: Observations with Eucalyptus and emission rate algorithm development, J. Geophys. Res., 96, 10799-10808, 1991.

Guenther, A., Hewitt, C. N., Erickson, D., Fall, R., Geron, C., Graedel, T., Harley, P., Klinger, L., Lerdau, M., McKay, W. A., Pierce, T., Scholes, B., Steinbrecher, R., Tallamraju, R., Taylor, J., and Zimmermann, P.: A global model of natural volatile organic compound emissions, J. Geophys. Res., 100, 8873-8892, 1995.

Guenther, A., Karl, T., Harley, P., Wiedinmyer, C., Palmer, P. I., and Geron, C.: Estimates of global terrestrial isoprene emissions using MEGAN (Model of Emissions of Gases and Aerosols from Nature), Atmos. Chem. Phys., 6, 3181-3210, doi:10.5194/acp-63181-2006, 2006.

Hansen, M., DeFries, R. S., Townshend, J. R. G., Carroll, M., Dimiceli, C., and Sohlberg, R. A.: Global percent tree cover at a spatial resolution of 500 meters: first results of the MODIS vegetation continuous fields algorithm, Earth Interact., 7, 1-15, 2003. Hauglustaine, D. A., Lathiere, J., Szopa, S., and Folberth,
G. A.: Future tropospheric ozone simulated with a climatechemistry-biosphere model, Geophys. Res. Lett., 32, L24807, doi:10.1029/22005GL024031, 2005.

Heald, C. L., Wilkinson, M. J., Monson, R. K., Alo, C. A., Wang, G. L., and Guenther, A.: Response of isoprene emission to ambient $\mathrm{CO}_{2}$ changes and implications for global budgets, Glob. Change Biol., 15, 1127-1140, doi:10.1111/j.1365-2486.2008.01802.x, 2009.

Hickler, T., Smith, B., Prentice, I. C., Mjöfors, K., Miller, P., Arneth, A., and Sykes, M.: $\mathrm{CO}_{2}$ fertilization in temperate FACE experiments not representative of boreal and tropical forests, Global Change Biol., 14, 1-12, doi:10.1111/j.13652486.2008.01598.x, 2008.

Huete, A. R., Didan, K., Shimabukuro, Y. E., Ratana, P., Saleska, S. R., Hutyra, L. R., Yang, W., Nemani, R. R., and Myneni, R.: Amazon rainforests green-up with sunlight in dry season, Geophys. Res. Lett., 33, L06405, doi:10.1029/2005gl025583, 2006.

Karl, T., Potosnak, M., Guenther, A., Clark, D., Walker, J., Herrick, J. D., and Geron, C.: Exchange processes of volatile organic compounds above a tropical rain forest: Implications for modeling tropospheric chemistry above dense vegetation, J. Geophys. Res., 109, D18306, doi:10.11029/12004JD004738, 2004.

Karl, T. G., Christian, T. J., Yokelson, R. J., Artaxo, P., Hao, W. M., and Guenther, A.: The tropical forest and fire emissions experiment: method evaluation of volatile organic compound emissions measured by PTR-MS, FTIR, and GC from tropical biomass burning, Atmos. Chem. Phys., 7, 5883-5897, doi:10.5194/acp-7-5883-2007, 2007.

Kiendler-Scharr, A., Wildt, J., Maso, M. D., Hohaus, T., Kleist, E., Mentel, T. F., Tillmann, R., Uerlings, R., Schurr, U., and Wahner, A.: New particle formation in forests inhibited by isoprene emissions, Nature, 461, 381-384, doi:10.1038/nature08292, 2009.

Kistler, R., Kalnay, E., Collins, W., Saha, S., White, G., Woollen, J., Chelliah, M., Ebisuzaki, W., Kanamitsu, M., Kousky, V., van den Dool, H., Jenne, R., and Fiorino, M.: The NCEP-NCAR 50year reanalysis: Monthly means CD-ROM and documentation, Bulletin of the American Meteorological Society, 82, 247-267, 2001.

Körner, C.: Plant $\mathrm{CO}_{2}$ responses: an issue of definition, time and resource supply, New Phytol., 172, 393-411, 2006.

Kuhn, U., Rottenberger, S., Biesenthal, T., Wolf, A., Schebeske, G., Ciccioli, P., and Kesselmeier, J.: Strong correlation between isoprene emission and gross photosynthetic capacity during leaf phenology of the tropical tree species Hymenaea courbaril with fundamental changes in volatile organic compounds emission composition during early leaf development, Plant, Cell, Environ., 27, 1469-1485, 2004.

Lathière, J., Hauglustaine, D. A., Friend, A., De Noblet-Ducoudré, N., Viovy, N., and Folberth, G.: Impact of climate variability and land use changes on global biogenic volatile organic compound emissions, Atmos. Chem. Phys., 6, 2129-2146, doi:10.5194/acp6-2129-2006, 2006.

Lathière, J., Hewitt, C. N., and Beerling, D. J.: Sensitivity of isoprene emissions from the terrestrial biosphere to 20th century changes in atmospheric $\mathrm{CO}_{2}$ concentration, climate, and land use, Glob. Biogeochem. Cycl., 24, GB1004, doi:10.1029/2009GB003548, 2010.

Lelieveld, J., Butler, T. M., Crowley, J. N., Dillon, T. J., Fischer, H., Ganzeveld, L., Harder, H., Lawrence, M. G., Martinez, M., 
Taraborrelli, D., and Williams, J.: Atmospheric oxidation capacity sustained by a tropical forest, Nature, 452, 737-740, 2008.

Levis, S., Wiedinmyer, C., Bonan, G. B., and Guenther, A.: Simulating biogenic volatile organic compound emissions in the Community Climate System Model, J. Geophys. Res., 108, 4659, doi:10.1029/2002JD003203, 2003.

Li, D. W., Chen, Y., Shi, Y., He, X. Y., and Chen, X.: Impact of elevated $\mathrm{CO}_{2}$ and $\mathrm{O}_{3}$ concentrations on biogenic volatile organic compounds emissions from Ginkgo biloba, Bull. Environ. Contam. Toxicol., 82, 473-477, doi:10.1007/s00128-008-95907, 2009.

Lichtenthaler, H. K.: The 1-deoxy-D-xylulose-5-phosphate pathway of isoprenoid biosynthesis in plants, Ann. Rev. Plant Phys. Plant Mol. Biol., 50, 47-65, 1999.

Lucht, W., Prentice, I. C., Myneni, R. B., Sitch, S., Friedlingstein, P., Cramer, W., Bousquet, P., Buermann, W., and Smith, B.: Climatic control of the high-latitude vegetation greening trend and Pinatubo effect, Science, 296, 1687-1689, 2002.

Mitchell, T. D. and Jones, P. D.: An improved method of constructing a database of monthly climate observations and associated high-resolution grids, Int. J. Climatol., 25, 693-712, 2005.

Monson, R. K. and Fall, R.: Isoprene emission from aspen leaves: Influence of environment and relation to photosynthesis and photorespiration, Plant Phys., 90, 267-274, 1989.

Monson, R. K.,Trahan, N., Rosenstiel, T. N.,Veres, P., Moore, D., Wilkinson, M., Norby, R. J.,Volder, A.,Tjoelker, M. G.,Briske, D. D., Karnosky, D. F., and Fall, R.: Isoprene emission from terrestrial ecosystems in response to global change: minding the gap between models and observations, Phil. Trans. Roy. Soc. A, 365, 1677-1695, 2007.

Monteith, J. L. and Unsworth, M.: Principles of Environmental Physics, 2nd ed., Arnold, London, 1990.

Morales, P., Sykes, M. T., Prentice, I. C., Smith, P., Smith, B., Bugmann, H., Zierl, B., Friedlingstein, P., Viovy, N., Sabate, S., Sanchez, A., Pla, E., Gracia, C. A., Sitch, S., Arneth, A., and Ogee, J.: Comparing and evaluating process-based ecosystem model predictions of carbon and water fluxes in major European forest biomes, Global Change Biol., 11, 2211-2233, 2005.

Muller, J. F., Stavrakou, T., Wallens, S., De Smedt, I., Van Roozendael, M., Potosnak, M. J., Rinne, J., Munger, B., Goldstein, A., and Guenther, A. B.: Global isoprene emissions estimated using MEGAN, ECMWF analyses and a detailed canopy environment model, Atmos. Chem. Phys., 8, 1329-1341, doi:10.5194/acp-81329-2008, 2008.

Myneni, R. B., Yang, W. Z., Nemani, R. R., Huete, A. R., Dickinson, R. E., Knyazikhin, Y., Didan, K., Fu, R., Juarez, R. I. N., Saatchi, S. S., Hashimoto, H., Ichii, K., Shabanov, N. V., Tan, B., Ratana, P., Privette, J. L., Morisette, J. T., Vermote, E. F., Roy, D. P., Wolfe, R. E., Friedl, M. A., Running, S. W., Votava, P., El-Saleous, N., Devadiga, S., Su, Y., and Salomonson, V. V.: Large seasonal swings in leaf area of Amazon rainforests, Proc. Natl. Acad. Sci. USA, 104, 4820-4823, doi:10.1073/pnas.0611338104, 2007.

Naik, V., Delire, C., and Wuebbles, D. J.: Sensitivity of global biogenic isoprenoid emissions to climate variability and atmospheric $\mathrm{CO}_{2}$, J. Geophys. Res., 109, D06301, doi:10.01029/02003JD004236, 2004.

Niinemets, U., Tenhunen, J. D., Harley, P. C., and Steinbrecher, R.: A model of isoprene emission based on energetic requirements for isoprene synthesis and leaf photosynthetic properties for Liquidambar and Quercus, Plant, Cell, Environ., 22, 1319-1335, 1999.

Niinemets, Ü., Arneth, A., Kuhn, U., Monson, R. K., Peñuelas, J., and Staudt, M.: The emission factor of volatile isoprenoids: stress, acclimation, and developmental responses, Biogeosciences, 7, 2203-2223, doi:10.5194/bg-7-2203-2010, 2010a.

Niinemets, Ü., Monson, R. K., Arneth, A., Ciccioli, P., Kesselmeier, J., Kuhn, U., Noe, S. M., Penuelas, J., and Staudt, M.: The emission factor of volatile isoprenoids: caveats, model algorithms, response shapes and scaling, Biogeosciences, 7, 18091832, doi:10.5194/bg-7-1809-2010, 2010b.

Pacifico, F., Harrison, S. P., Jones, C. D., Arneth, A., Sitch, S., Weedon, G. P., Barkley, M. P., Palmer, P. I., Serça, D., Potosnak, M., Fu, T. M., Goldstein, A., Bai, J., and Schurgers, G.: Evaluation of a photosynthesis-based biogenic isoprene emission scheme in JULES and simulation of isoprene emissions under modern climate conditions, Atmos. Chem. Phys., 11, 4371-4389, doi:10.5194/acp-11-4371-2011, 2011.

Palmer, P. I., Abbot, D. S., Fu, T. M., Jacob, D. J., Chance, K., Kurosu, T. P., Guenther, A., Wiedinmyer, C., Stanton, J. C., Pilling, M. J., Pressley, S. N., Lamb, B., and Sumner, A. L.: Quantifying the seasonal and interannual variability of North American isoprene emissions using satellite observations of the formaldehyde column, J. Geophys. Res., 111, D12315, doi:10.11029/12005JD006689, 2006.

Pfister, G. G., Emmons, L. K., Hess, P. G., Lamarque, J. F., Orland o, J. J., Walters, S., Guenther, A., Palmer, P. I., and Lawrence, P. J.: Contribution of isoprene to chemical budgets: A model tracer study with the NCAR CTM MOZART-4, J. Geophys. Res., 113, D05308, doi:10.01029/02007JD008948, 2008.

Poisson, N., Kanakidou, M., and Crutzen, P. J.: Impact of non-methane hydrocarbons on tropospheric chemistry and the oxidizing power of the global troposphere: 3dimensional modelling results, J. Atmos. Chem., 36, 157-203, doi:10.1023/A:1006300616544, 2000.

Possell, M., Hewitt, N. C., and Beerling, D. J.: The effects of glacial atmospheric $\mathrm{CO}_{2}$ concentrations and climate on isoprene emissions by vascular plants, Global Change Biol., 11, 60-69, 2005.

Possell, M. and Hewitt, C. N.: Isoprene emissions from plants are mediated by atmospheric $\mathrm{CO}_{2}$ concentrations, Global Change Biol., doi:10.1111/j.1365-2486.2010.02306.x, 2010.

Prather, M., Ehhalt, D., Dentener, F. J., Derwent, R., Dlugokencky, E. J., Holland, E., Isaksen, I., Katima, J., Kirchhoff, V., Matson, P., Midgley, P., M., W., and al., e.: Atmospheric chemistry and greenhouse gases, in: Climate Change 2001. The Scientific Basis. Contribution of Working Group I to the Third Assessment Report of the Intergovernmental Panel on Climate Change, edited by: Houghton, J. T., Ding, Y., Griggs, D. J., Noguer, M., van der Linden, P. J., Dai, X., Maskell, K., and Johnson, C. A., University Press, Cambridge, 238-287, 2001.

Pressley, S., Lamb, B., Westberg, H., Flaherty, J., Chen, J., and Vogel, C.: Long-term isoprene flux measurements above a northern hardwood forest, J. Geophys. Res., 110, D07301, doi:07310.01029/02004JD005523, 2005.

Rosenstiel, T. N., Potosnak, M. J., Griffin, K. L., Fall, R., and Monson, R. K.: Increased $\mathrm{CO}_{2}$ uncouples growth from isoprene emission in an agriforest ecosystem, Nature, 421, 256- 
259, doi:210.1038/nature01312, 2003.

Rosenstiel, T. N., Ebbets, A. L., Khatri, W. C., Fall, R., and Monson, R. K.: Induction of Poplar leaf nitrate reductase: A test of extrachloroplastic control of isoprene emission rate, Plant Biol., 6, 12-21, 2004.

Sanderson, M. G., Jones, C. D., Collins, W. J., Johnson, C. E., and Derwent, R. G.: Effect of climate change on isoprene emissions and surface ozone levels, Geophys. Res. Lett., 30, 1936, doi:1910.1029/2003GL017642, 2003.

Schaphoff, S., Lucht, W., Gerten, D., Sitch, S., Cramer, W., and Prentice, I. C.: Terrestrial biosphere carbon storage under alternative climate projections, Clim. Change, 74, 97-122, 2006.

Scholefield, P. A., Doick, K. J., Herbert, B. M. J., Hewitt, C. N. S., Schnitzler, J. P., Pinelli, P., and Loreto, F.: Impact of rising $\mathrm{CO}_{2}$ on emissions of volatile organic compounds: isoprene emission from Phragmites australis growing at elevated $\mathrm{CO}_{2}$ in a natural carbon dioxide spring, Plant, Cell, Env., 27, 393-401, doi:10.1111/j.1365-3040.2003.01155.x, 2004.

Schurgers, G., Hickler, T., Miller, P. A., and Arneth, A.: European emissions of isoprene and monoterpenes from the Last Glacial Maximum to present, Biogeosciences, 6, 2779-2797, doi:10.5194/acp-9-2779-2009, 2009.

Schurgers, G., Arneth, A., and Hickler, T.: The effect of species composition on plant functional type emission capacities of biogenic compounds, J. Geophys. Res., in review, 2011.

Sharkey, T. D., Loreto, F., and Delwiche, C. F.: High-carbon dioxide and sun shade effects on isoprene emission from oak and aspen tree leaves, Plant Cell Environ., 14, 333-338, 1991.

Shim, C., Wang, Y. H., Choi, Y., Palmer, P. I., Abbot, D. S., and Chance, K.: Constraining global isoprene emissions with Global Ozone Monitoring Experiment (GOME) formaldehyde column measurements, J. Geophys. Res., 110, D24301, doi:10.1029/2004JD005629, 2005.

Sitch, S., Smith, B., Prentice, I. C., Arneth, A., Bondeau, A., Cramer, W., Kaplan, J. O., Levis, S., Lucht, W., Sykes, M. T., Thonicke, K., and Venevsky, S.: Evaluation of ecosystem dynamics, plant geography and terrestrial carbon cycling in the LPJ dynamic global vegetation model, Global Change Biol., 9, 161185, 2003.

Smith, B., Prentice, I. C., and Sykes, M. T.: Representation of vegetation dynamics in the modelling of terrestrial ecosystems: comparing two contrasting approaches within European climate space, Glob. Ecol. Biogeosci., 10, 621-637, 2001.

Staniforth, A., White, A., Wood, N., Thuburn, J., Zerroukat, M., Cordero, E., and Davies, T.: Joy of U.M. 6.1: Model Formulation, Unified Model Doc. Paper 15, Exeter, UK, 2005.

Stavrakou, T., Müller, J. F., De Smedt, I., Van Roozendael, M., van der Werf, G. R., Giglio, L., and Guenther, A.: Global emissions of non-methane hydrocarbons deduced from SCIAMACHY formaldehyde columns through 2003-2006, Atmos. Chem. Phys., 9, 3663-3679, doi:10.5194/acp-9-3663-2009, 2009.
Stavrakou, T., Peeters, J., and Müller, J. F.: Improved global modelling of HOx recycling in isoprene oxidation: evaluation against the GABRIEL and INTEX-A aircraft campaign measurements, Atmos. Chem. Phys., 10, 9863-9878, doi:10.5194/acp-10-98632010, 2010.

Stevenson, D. S., Dentener, F. J., Schultz, M. G., Ellingsen, K., van Noije, T. P. C., Wild, O., Zeng, G., Amann, M., Atherton, C. S., Bell, N., Bergmann, D. J., Bey, I., Butler, T., Cofola, J., Collins, W. J., Derwent, R. G., Doherty, R. M., Drevet, J., Eskes, H. J., Fiore, A. M., Gauss, M., Hauglustaine, D. A., Horowitz, L. W., Isaksen, I. S. A., Krol, M. C., Lamarque, J. F., Lawrence, M. G., Montanaro, V., Muller, J. F., Pitari, G., Prather, M. J., Pyle, J. A., Rast, S., Rodriguez, J. M., Sanderson, M. G., Savage, N. H., Shindell, D. T., Strahan, S. E., Sudo, K., and Szopa, S.: Multi-model ensemble simulations of present-day and near-future tropospheric ozone, J. Geophys. Res., 111, D08301, doi:10.01029/02005JD006338, 2006.

Telford, P. J., Lathière, J., Abraham, N. L., Archibald, A. T., Braesicke, P., Johnson, C. E., Morgenstern, O., O’Connor, F. M., Pike, R. C., Wild, O., Young, P. J., Beerling, D. J., Hewitt, C. N., and Pyle, J.: Effects of climate-induced changes in isoprene emissions after the eruption of Mount Pinatubo, Atmos. Chem. Phys., 10, 7117-7125, doi:10.5194/acp-10-7117-2010, 2010.

Wiberley, A. E., Linskey, A. R., Falbel, T. G., and Sharkey, T. D.: Development of the capacity for isoprene emission in Kudzu, Plant, Cell, Env., 28, 898-905, 2005.

Wilkinson, M., Monson, R. K., Trahan, N., Lee, S., Brown, E., Jackson, R. B., Polley, H. W., Fay, P. A., and Fall, R.: Leaf isoprene emission rate as a function of atmospheric $\mathrm{CO}_{2}$ concentration, Glob. Change Biol., 15, 1189-1200, doi:10.1111/j.13652486.2008.01803.x, 2009.

Woodward, F. I., Smith, T. M., and Emanuel, W. R.: A global land primary productivity and phytogeography model, Glob. Biogeochem. Cy., 9, 471-490, doi:10.1029/1095GB02432, 1995.

Young, P. J., Arneth, A., Schurgers, G., Zeng, G., and Pyle, J.: The $\mathrm{CO}_{2}$ inhibition of terrestrial isoprene emission significantly affects future ozone projections, Atmos. Chem. Phys., 9, 2793 2803, doi:10.5194/acp-9-2793-2009, 2009.

Zhang, P., And erson, B., Barlow, M., Tan, B., and Myneni, R.: Climate related vegetation characteristics derived from MODIS LAI and NDVI, J. Geophys. Res., 109, D20105, doi:10.21029/22004JD004720, 2004. 